\title{
Rancang Bangun Sistem Informasi Sebagai Media Promosi Untuk Usaha Mikro Kecil Menengah (UMKM)
}

\author{
Yonanda Aditama Sari ${ }^{1)}$, Ridho Pamungkas ${ }^{2)}$, Andria $^{3)}$ \\ Sistem Informasi, Universitas PGRI Madiun, Jl. Setia Budi NO.85, Kanigoro, \\ Kec, Kartoharjo, Kota Madiun, Jawa Timur 63118 \\ E-mail:yonandamasifunipma@gmail.com ${ }^{1)}$, ridho.pamungkas@unipma.ac.id ${ }^{2)}$, andria@unipma.ac.id ${ }^{3)}$
}

\begin{abstract}
The use of technology in the business sector is not only for large businesses and companies that are growing rapidly, but also for UMKM. With this technology can increase the number of turnover and increase the number of customers. Previously shining UMKM had utilized information media such as Facebook and Instagram. In managing UMKM Bersinar uses Facebook and Instagram and is managed directly by the chairman of UMKM Bersinar using a personal account. Based on the results of interviews and observations of the UMKM Bersinar owners, there were several obstacles experienced during the marketing of the UMKM Bersinar product business, only Facebook and Instagram users who were friends with the UMKM Bersinar chairman who had facts about the UMKM Bersinar product.In the obstacles experienced by the UMKM Bersinar, it can be concluded that the ongoing problem is what technology can market the UMKM Bersinar product widely and thoroughly. One solution to this problem is to build a website-based marketing and promotion information system that shines UMKM need
\end{abstract}

Keywords—: Management information system; waterfall method; UMKM Bersinar

\section{PENDAHULUAN}

Perkembangan dalam dunia bisnis telah mengubah banyak hal terutama dalam dunia bisnis dimana teknologi digunakan sebagai alat untuk membantu mereka bekerja. Hal ini membuat persaingan dalam dunia bisnis berkembang lebih cepat, terutama di bidang bisnis, usaha mikro, kecil dan menengah (UMKM). Untuk menjadi kompetitif, kegiatan usaha khususnya usaha kecil, menengah dan mikro harus dapat memiliki konsep untuk menata kondisi usahanya dengan lebih baik. Mendukung secara efektif dan efisien, yaitu melalui penggunaan sistem informasi. Perkembangan perusahaan yang semakin kompetitif akan berdampak pada maksimalisasi keuntungan.

Ada kebutuhan besar untuk pengembangan sistem informasi komputerisasi untuk meningkatkan pengendalian internal. Sistem informasi internal adalah sistem yang menghasilkan informasi berikut diperlukan untuk kegiatan bisnis dalam bentuk pemrosesan data transaksi. Kegiatan bisnis yang didukung oleh sistem informasi akan diuntungkan dengan mendorong pemilik bisnis untuk mengelola data secara lebih efektif. Oleh karena itu, sistem informasi akan sangat berguna untuk pelaku usaha khususnya usaha kecil dan menengah (UMKM). Kegiatan penjualan membutuhkan sistem informasi yang terkomputerisasi untuk memberikan informasi yang andal dan akurat. Memiliki sistem informasi yang

terkomputerisasi akan meningkatkan manajemen dan pengendalian kontrol internal yang sangat baik untuk menghindari kesalahan penulisan dan kehilangan dokumen. Hal ini sangat dibutuhkan oleh UMKM (Rahmawati \& Mulyono, 2016).

Objek penelitian ini adalah UMKM Bersinar yang merupakan salah satu UMKM dibidang pembuatan aneka souvenir seperti,cangkang kerang,sapu dari serat kelapa, vas bunga/pot bunga dan aneka makanan kuliner roti, tumpeng, makanan tradisional, makanan ringan untuk hajatan. UMKM Bersinar berada di Desa Goranggareng sejak tahun 2019. Penjualan UMKM Bersinar masih dilakukan secara tunai dengan memakai uang muka, pembayaran datang langsung ke lokasi dapat melakukan pembayaran uang muka pelanggan yang melakukan pemesanan souvenir dan makanan kuliner pada UMKM Bersinar terdiri dari pelanggan tetap dan pelanggan baru. Jumlah pelanggan melakukan pemesanan makanan kuliner di UMKM Bersinar per minggunya berkisar 1-dua orang untuk pelanggan tetap dan berkisar dua-tiga orang untuk pelanggan baru.

Pemanfaat teknologi di bidang bisnis tidak hanya pada usaha-usaha besar maupun perusahan yang berkembang pesat namun juga pada UMKM. Dengan adanya teknologi ini dapat meningkatkan jumlah omset dan menaikan jumlah pelanggan. Sebelumnya UMKM bersinar telah memanfaatkan media 
Website : http://pilar.unmermadiun.ac.id/index.php/pilarteknologi

informasi seperti Facebook dan Instagram. Dalam mengelola UMKM Bersinar menggunakan Facebook dan Instagram dan dikelola langsung oleh ketua UMKM Bersinar dengan menggunakan akun pribadi. Berdasarkan hasil wawancara dan observasi pemilik UMKM Bersinar, ada beberapa hambatan yang dialami selama pemasaran usaha produk UMKM Bersinar hanya pengguna Facebook dan Instagram yang berteman dengan ketua UMKM Bersinar yang mengetahui tentang produk UMKM Bersinar.

Dalam hambatan yang dialami UMKM Bersinar, bisa disimpulkan permasalahan yang berlangsung merupakan teknologi apa yang bisa memasarkan produk UMKM Bersinar secara luas dan menyeluruh. Salah satu solusi untuk masalah tersebut adalah membangun sistem informasi pemasaran dan promosi berbasis website yang dibutuhkan UMKM bersinar.

\section{METODE PENELITIAN}

Penelitian bertempat Desa Goranggareng Kecamatan Nguntoronadi Kabupaten Magetan. UMKM Bersinar Memiliki kerjinan cangkang kerang dan makanan kuliner vas/pot bunga dan kerajinan sapu dari sabut kelapa. Dalam pengembangan sistem informasi ini menggunakan metode waterfall.

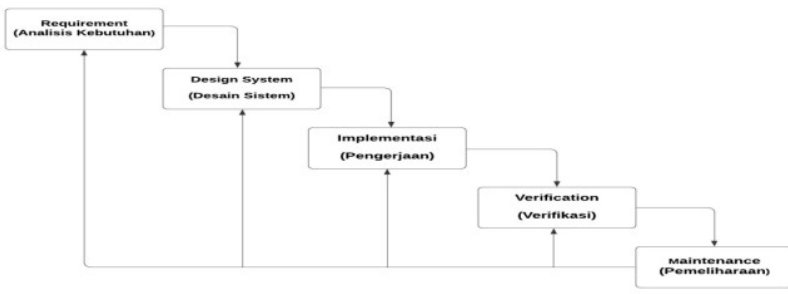

Gambar 1. Metode Waterfall(Handrianto \& Sanjaya, 2020).

\section{Requirement (Analisis Kebutuhan)}

Kebutuhan adalah sebuah proses menganalisis setiap mengumpulkan data relevan dengan menggunakan sistem untuk membuat. Pengumpulan data ini dapat dilakukan melalui wawancara, penelitian kepustakaan, pengamatan atau penyelidikan langsung. Pada tahap ini, tim akan menggali informasi sebanyak mungkin berdasarkan perangkat lunak yang di inginkan pelanggan. Setelah melakukan wanwancara terhadap ketua UMKM Bersinar maka dapat disimpulkan dari kebutuhan UMKM Bersinar dengan dibangun website.

\section{Design System (Desain Sistem)}

Teknik ini akan berfokus pada membangun data, arsitektur perangkat lunak, desain antarmuka, merancang fungsi dan detail internal dan eksternal berdasarkan algoritma masing-masing program. Di tahap ini memulai memproses dan mendesain sistem informasi pemasaran sebagai media promosi untuk UMKM Bersinar Desa Goranggareng Kecamatan Nguntoronadi Kabupaten Magetan.

\section{Implementasi (Pengerjaan)}

Tahap ini merupakan tahapan dimana kode bahasa pemrograman tertentu digunakan untuk membuat program aplikasi seorang programmer. Proses penulisan kode sinkronisasi (encoding) mengacu pada dokumen tertulis sebelumnya. Dalam dokumen di atas, selalu ada kerusakan modul sistem naik beberapa programmer mampu bekerja pada aplikasi pada saat yang sama secara keseluruhan tanpa menggangu sistem lain. Fase implementasi juga dianggap sebagai fase kode. atau juga dianggap sebagai fase integrasi dan pengujian sistem. Mulai merancang sistem yang dibuat dan mengimplementasikan perancangan kedalam kode program.

\section{Verification (Verifikasi)}

Proses verifikasi mencangkup integrasi sistem, pengujian aplikasi yang dihasilkan. Sistem kemudian divalidasi untuk menguji kelayakannya. Pada tahap ini, semua modul akan diselesaikan oleh programmer yang berbeda akan digabungkan kemudian diuji dan kemudian diperbaiki kembali apakah sudah sinkron dengan spesifikasi yang ditentukan atau ada kesalahan/error pada sistem. Setelah selesainya rancang bangun website UMKM Bersinar kemudian akan di uji melalui blackbox testing 
Website : http://pilar.unmermadiun.ac.id/index.php/pilarteknologi

dan whitebox testing untuk melihat apakah sistem yang dibangun telah berfungsi sebagaimana mestinya.

\section{Maintenance (Pemeliharaan)}

Langkah ini biasanya mencakup instalasi pengujian perangkat lunak dan aplikasi. Pemeliharaan merupakan tanggung jawab dari tim pengembangan untuk menentukan apakah aplikasi berjalan dengan mulus kemudian dikirimkan ke pelanggan beberapa waktu. Menurut definisi yang lebih besar pemeliharaan adalah proses meningkatkan aplikasi untuk bug maupun kerentanan keamanan, meningkatkan kinerja aplikasi, terjamin bahwa penyebaran dijalankan ke jangkauan baru, dan menambahkan modul baru dan pengembangan implementasi.

\section{HASIL DAN PEMBAHASAN}

Pada bagian hasil dan pembahasan akan di paparkan mengenai perancangan UML, implementasi sistem.

\section{A. Use Case Diagram}

Use case Diagram adalah diagram yang dibuat pertama kali pada saat proses pemodelan perangkat lunak berorientasi objek.'

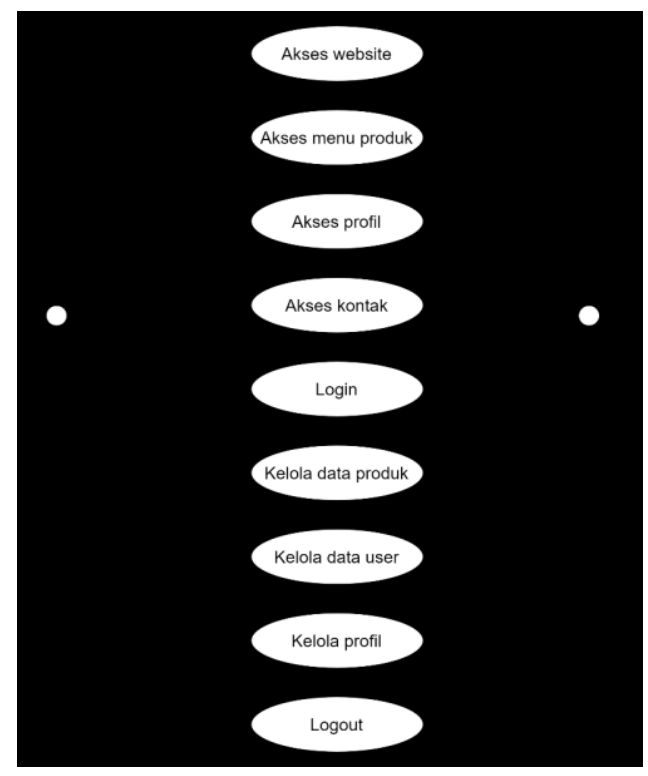

Gambar 2. Use Case Diagram

B. Class Diagram

Class Diagram adalah ilustrasi hubungan antara class yang dimodelkan didalam sistem Class Diagram sangat mirip dengan diagram hubungan entitas (ERD)(Wendi \& Ardiansyah, 2018).

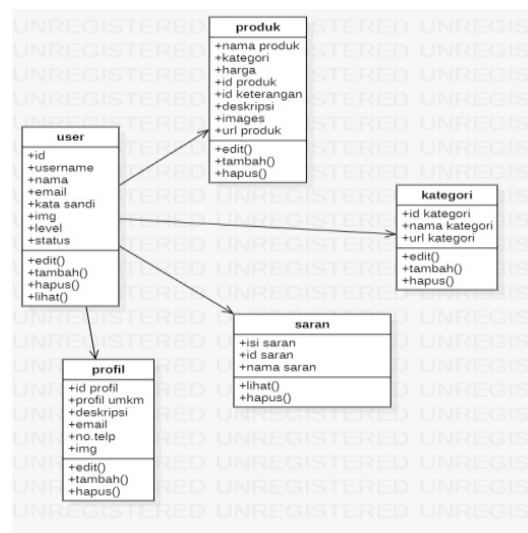

Gambar 3. Class Diagram 
C. Implementasi

1. Tampilan Halaman Beranda

Tampilan beranda adalah halaman utama untuk dapat koneksi dengan halaman-halaman pada website ini. Dimana pada halaman beranda terdapat fitur home, produk, profil, contact dan login Admin.

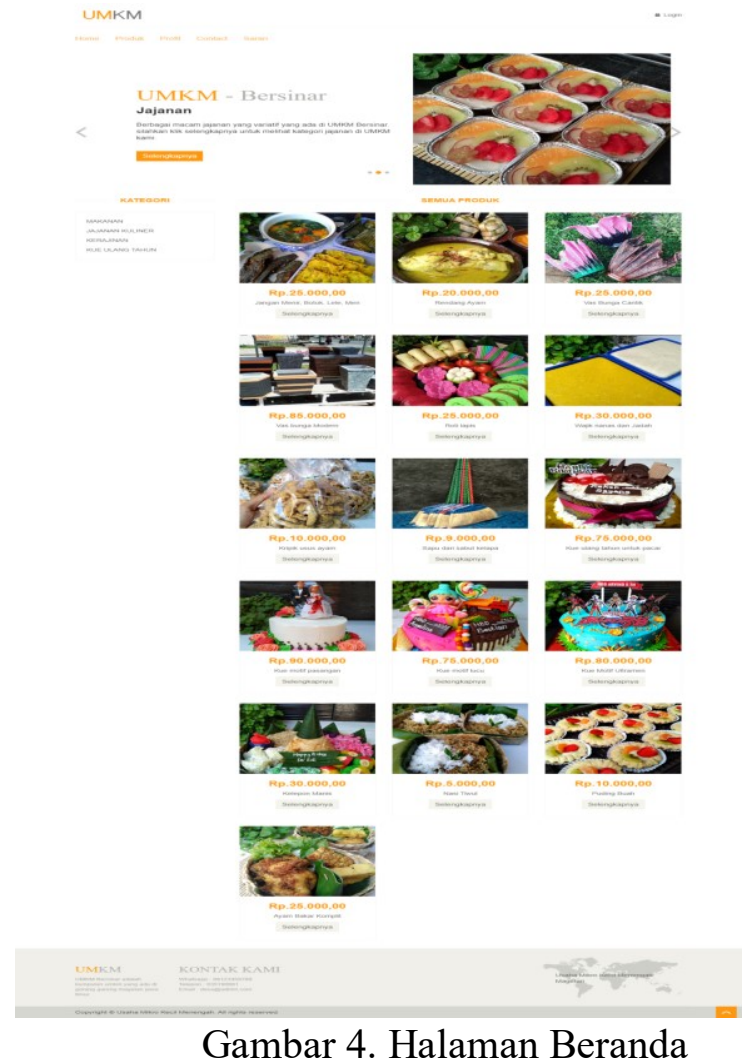

2. Tampilan Halaman Order

Pada halaman ini memeliki empat kategori contohnya kategori makanan dari UMKM Bersinar ditampilkan.
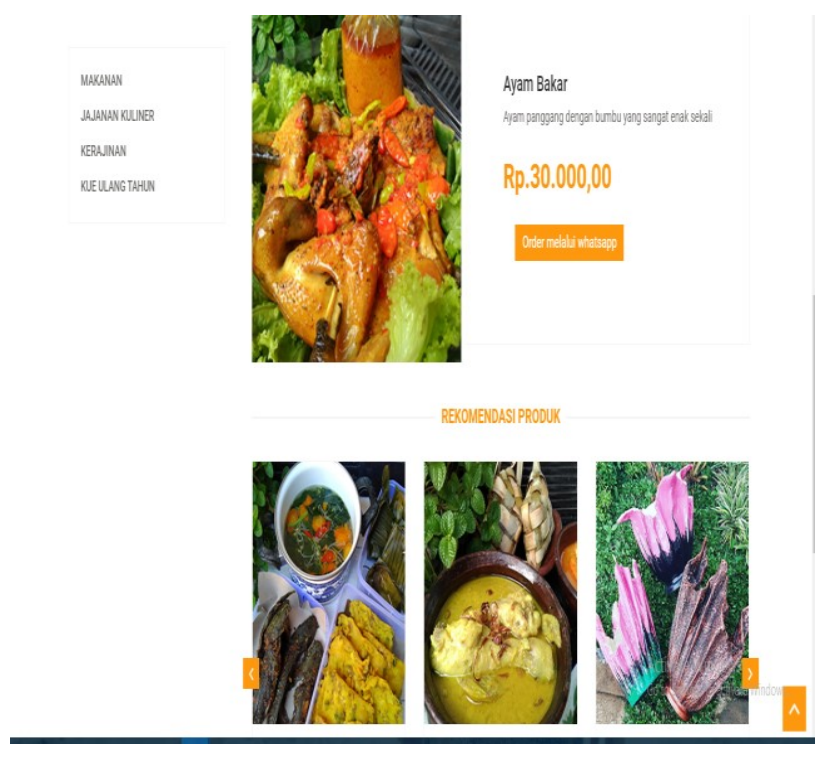

Gambar 5. Halaman Order 
Website : $\underline{\text { http://pilar.unmermadiun.ac.id/index.php/pilarteknologi }}$

3. Tampilan Halaman Whatsapp

Maka setelah klik order maka akan tertuju ke nomor Whatsapp pemilik UMKM.

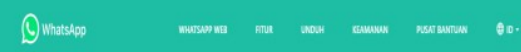

Chat di Whatsapp dengan $+62812-3448-6687$

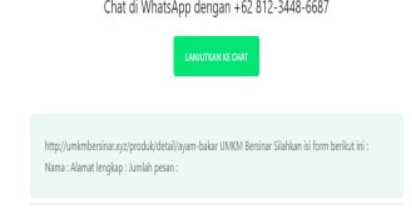

Gambar 6. Halaman Whatsapp

4. Tampilan Halaman Produk

Pada halaman produk berisi berbagai macam produk yang dijual oleh UMKM dan juga

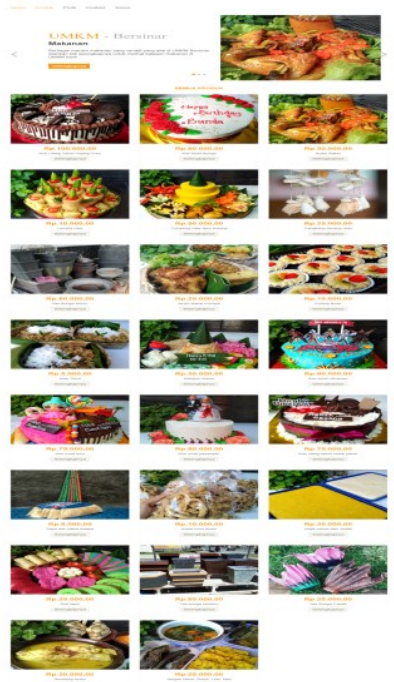

Gambar 7. Halaman produk

5. Tampilan Halaman Profil

Pada halaman profil menampilkan visi misi dari UMKM bersinar dan lokasi, serta menampilkan foto pengelola UMKM.

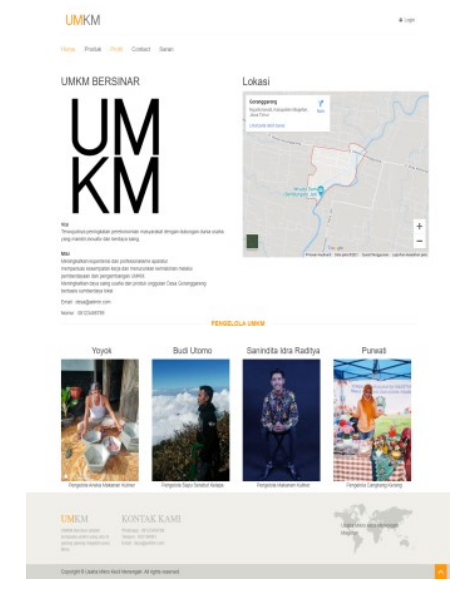

Gambar 8. Halaman Profil 
Website : http://pilar.unmermadiun.ac.id/index.php/pilarteknologi

6. Tampilan Halaman Contact

Pada halaman contact menampilkan hubungi kami jika terjadi kendala dalam mengakses website.
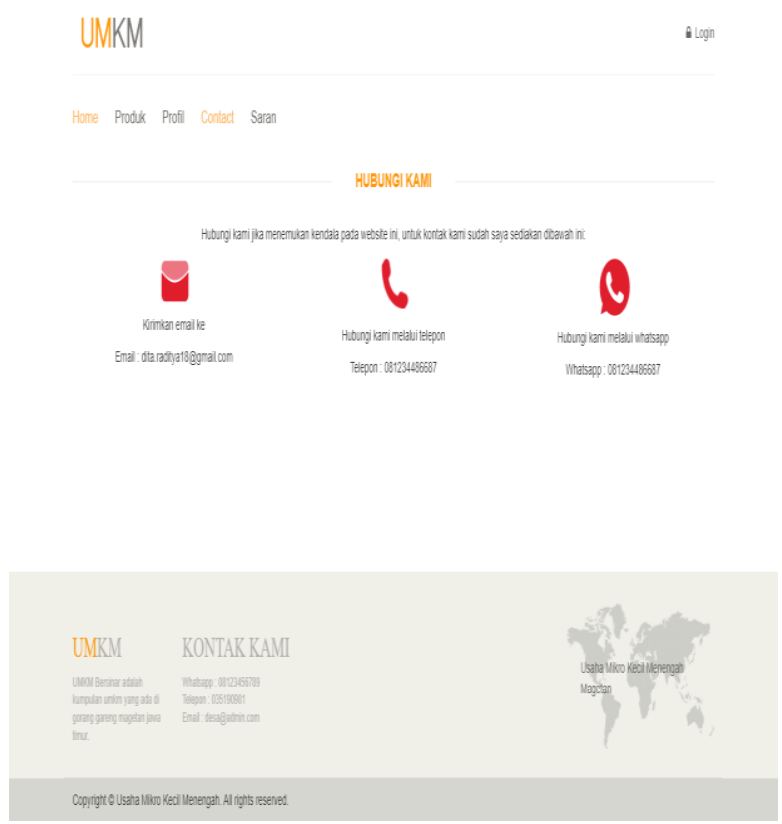

Gambar 9. Halaman contact

7. Tampilan Halaman Saran

Pada halaman saran kita bisa memberikan kritik dan saran setelah menggunakan website UMKM Bersinar berikut tampilan halaman saran.

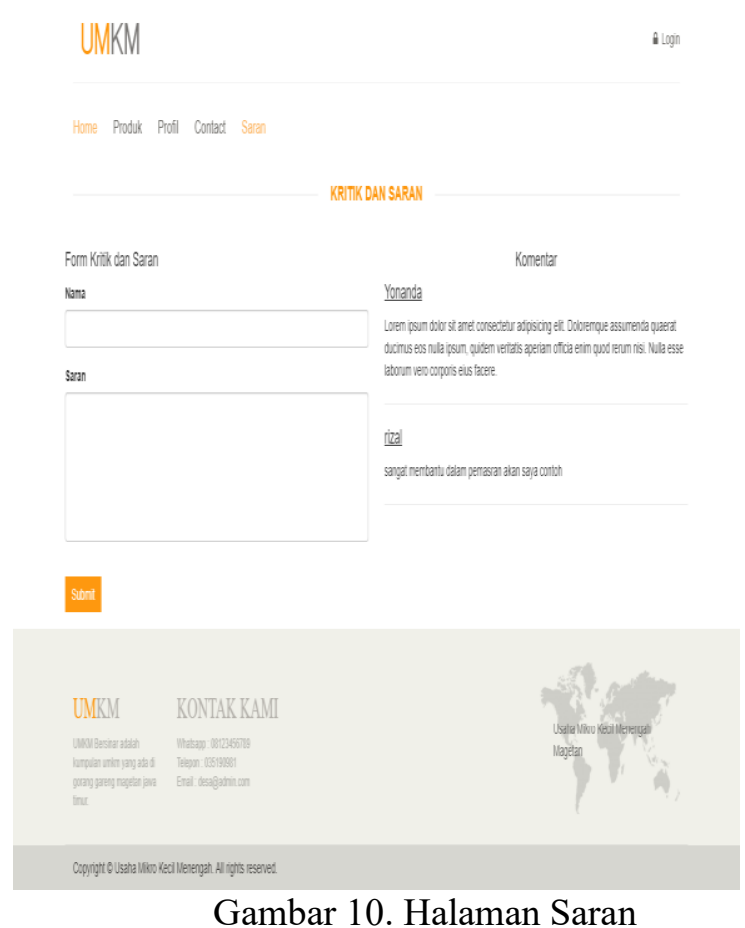

8. Tampilaan Halaman Dashboard Admin

Halaman Dashboard berisi tentang produk, data produk, kategori profil UMKM, kelola user. 
Website : $\underline{\text { http://pilar.unmermadiun.ac.id/index.php/pilarteknologi }}$

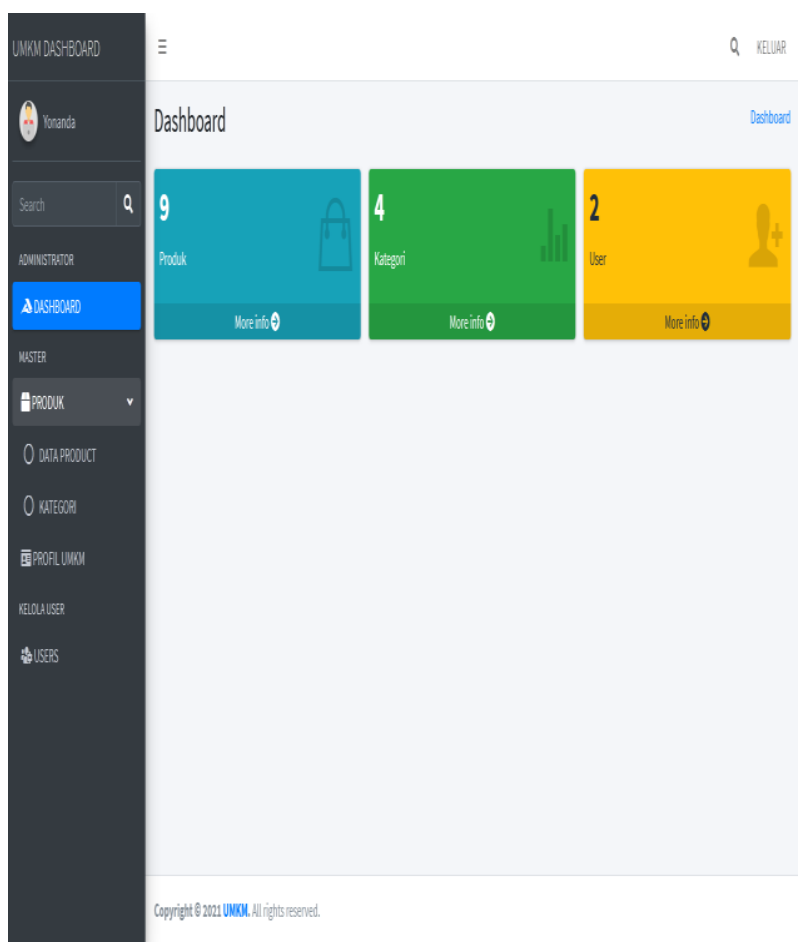

Gambar 11. Halaman Dashboard Admin

9. Tampilan Halaman Data Produk

Halaman data produk digunakan untuk menambah, mengedit, dan menghapus data produk yang hanya dapat dilakukan oleh admin

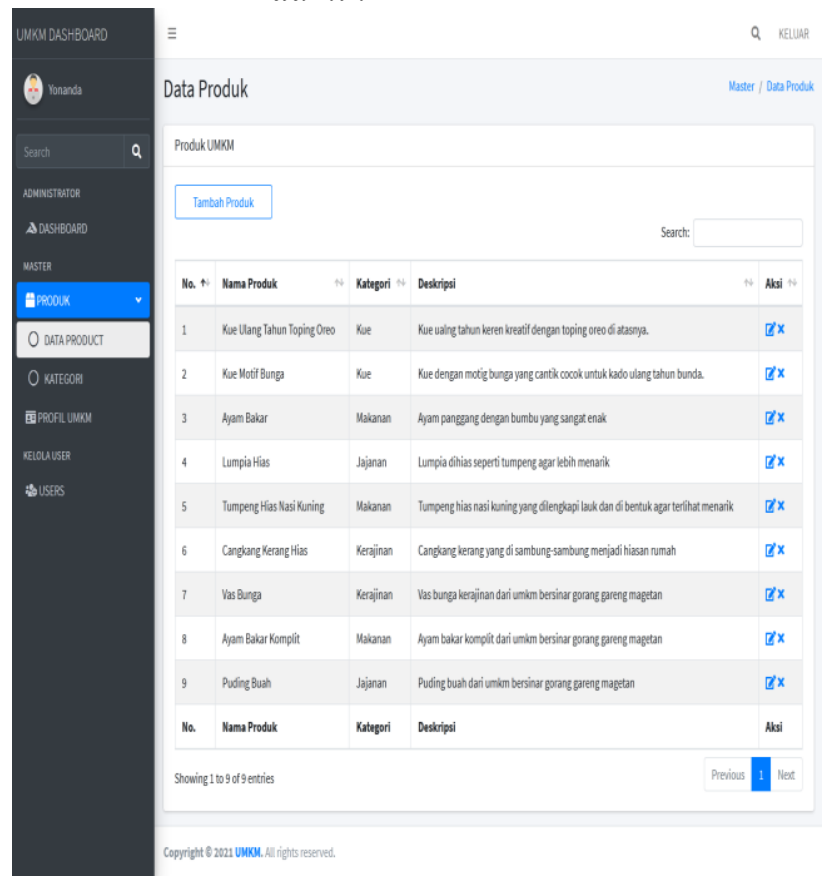

Gambar 12. Halaman Produk

10. Tampilan Halaman Kategori

Halaman kategori digunakan untuk menambahkan kategori dan mengedit, menghapus. 
Website : http://pilar.unmermadiun.ac.id/index.php/pilarteknologi

11. Tampilan Profil UMKM

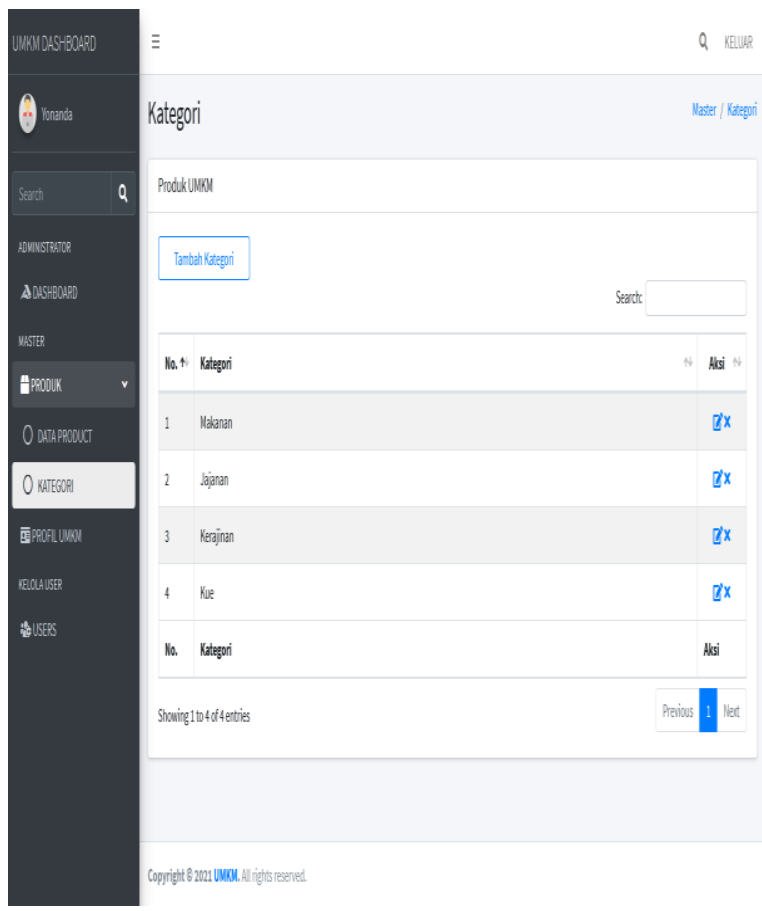

Gambar 13. Halaman Kategori

Halaman profil UMKM digunakan untuk mengedit nama UMKM, deskripsi, email, nomor telepon.
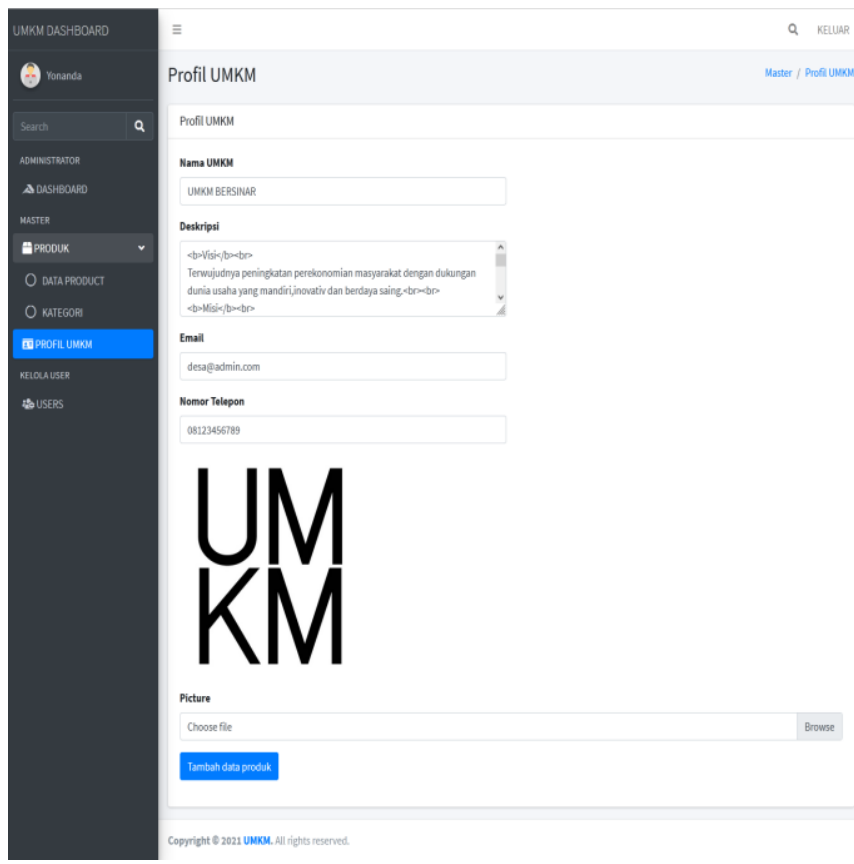

Gambar 14. Halaman Profil

12. Tampilan Halaman User

pada halaman user digunakan untuk menambahkan data Admin yang bisa login ke website UMKM Bersinar 
Website : http://pilar.unmermadiun.ac.id/index.php/pilarteknologi

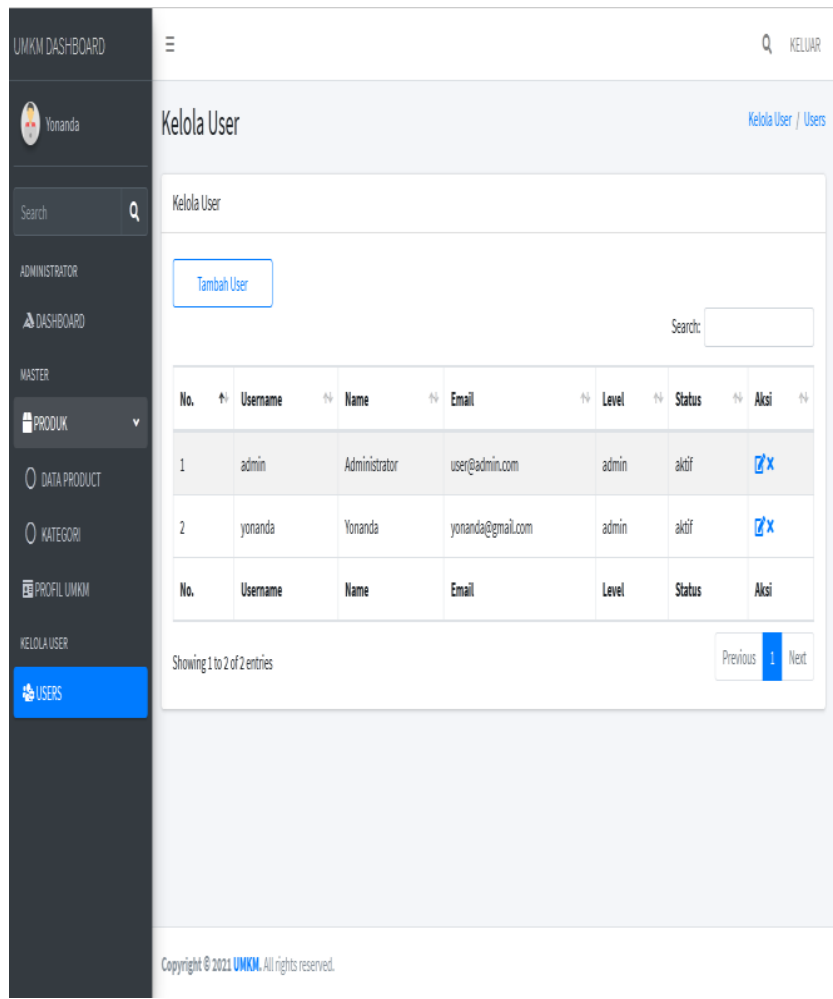

Gambar 15. Halaman User

\section{KESIMPULAN}

Kesimpulan yang didapat setelah rancang bangun sistem website akan dipergunakan untuk UMKM Bersinar Desa Goranggareng Kecamatan Nguntoronadi Kabupaten Magetan, dalam promosi dan pemasaran. Selain itu juga memudahkan konsumen untuk memesan dan menentukan produk yang akan dipilih konsumen didalam website sudah tertera Whatsapp pemilik UMKM Bersinar. Adapun kesimpulan lain berupa:

1. Sebelumnya ketua UMKM Bersinar dalam mempromosikan menggunakan media Facebook dan Instagram. Dengan ditambah adanya website akan mempermudah dalam menggunggah foto kedalam website dan diberi caption yang menarik.

2. Ketua UMKM Bersinar sering mengikuti lomba kerajinan hasil UMKM. Maka ada kesempatan mempromosikan dengan adanya website akan diberi akses berupa link agar bisa mengetahui apasaja hasil dari UMKM Bersinar lebih lengkap.

3. Website UMKM Bersinar cukup memadai dan mudah digunakan bagi masyarakat Desa Goranggareng untuk memajukan UMKM Desa tersebut.

\section{UCAPAN TERIMA KASIH}

Ucapan terimakasih penulis ucapkan kepada Bapak Ridho Pamungkas, S. Kom., M. Kom dan Bapak Andria S. Kom., M. Kom selaku dosen pembimbing yang telah meluangkan waktunya untuk membimbing dan berbagi ilmu dan masukan yang telah diberikan. Rasa terima kasih penulis ucapkan kepada ketua UMKM Bersinar Desa Goranggareng yang telah mendukung penelitian ini.

\section{DAFTAR PUSTAKA}

Fajariansyah, A. (2018). Animasi Interaktif Pembelajaran Kalimat Sederhana Dalam Bahasa Inggris Bagi Siswa Kelas V SD Muhammadiyah 47 Bekasi. 2(2), 207-220.

Handrianto, Y., \& Sanjaya, B. (2020). Model Waterfall Dalam Rancang Bangun Sistem Informasi Pemesanan Produk Dan Outlet Berbasis Web. Jurnal Inovasi Informatika, 5(2), 153-160. https://doi.org/10.51170/jii.v5i2.66 
Website : http://pilar.unmermadiun.ac.id/index.php/pilarteknologi

Hernandhi, D. T., Astuti, E. S., \& Priambada, S. (2018). Desain Sistem Informasi Pemasaran Berbasis Website Untuk Promosi ( Studi Kasus pada Kedai Ayam Geprak \& Sambal Bawang Malang ). Jurnal Administrasi Bisnis, 55(1), 1-10.

Hidayah, U., Mulatsih, S., \& Purnamadewi, Y. L. (2019). Analisis Kinerja Dan Strategi Pengembangan Umkm Alas Kaki Di Desa Pagelaran. Jurnal Benefita, 4(3), 435. https://doi.org/10.22216/jbe.v4i3.4232

Ii, B. A. B., Pustaka, T., \& Dasar, D. A. N. (2016). Bab II Tinjauan Pustaka Dan Dasar Teori 2.1 Tinjauan Pustaka Penelitian terkait dengan Metode. 2015, 5-11.

Leniwati, L., \& Arafat, Y. (2017). Implementasi Supervisi Akademik Kepala Sekolah Untuk Meningkatkan Kinerja Guru. JMKSP (Jurnal Manajemen, Kepemimpinan, Dan Supervisi Pendidikan), 2(1), 106-114. https://doi.org/10.31851/jmksp.v2i1.1158

Mluyati, S. S. (2019). Rancang Bangun Sistem Informasi Penyewaan Wedding Organizer Berbasis Web Dengan Php Dan Mysql Pada Kiki Rias. Jurnal Teknik, 7(2), 29-35. https://doi.org/10.31000/jt.v7i2.1355

Murah, H., Terdekat, D. A. N., \& Kota, D. I. (2021). Jurnal Comasie. 5.

Nur, H. (2019). Penggunaan Metode Waterfall Dalam Rancang Bangun Sistem Informasi Penjualan. Generation Journal, 3(1), 1. https://doi.org/10.29407/gj.v3i1.12642

Ortega, D., \& Alhifni, A. (2017). Pengaruh Media Promosi Perbankan Syariah Terhadap Minat Menabung Masyarakat Di Bank Syariah. Jurnal Ekonomi Syariah, 5(1), 87-98.

Rahmawati, N., \& Mulyono, H. (2016). Analisis dan Perancangan Sistem Informasi Pemasaran berbasis Web pada Toko Billy. Jurnal Manajemen Sistem Informasi, 1(2), 104-116. http://jurnalmsi.stikom-db.ac.id/index.php/jurnalmsi/article/view/44/38

Rosyadi, I., \& Sari, A. (2018). Sistem Informasi Pada “ Maya " Wedding Organizer Berbasis Website. Jurnal Surya Informatika, 5(1), 24-33.

Susilo, M. (2018). Rancang Bangun Website Toko Online Menggunakan Metode Waterfall. InfoTekJar (Jurnal Nasional Informatika Dan Teknologi Jaringan), 2(2), 98-105. https://doi.org/10.30743/infotekjar.v2i2.171

Syairozi, M. I., \& Susanti, I. (2018). Analisis Jumlah Pengangguran dan Ketenagakerjaan terhadap Keberadaan Usaha Mikro Kecil dan Menengah di Kabupaten Pasuruan. Jurnal Samudra Ekonomi Dan Bisnis, 9(2), 198-208. https://doi.org/10.33059/jseb.v9i2.768

Trilaksono, A., Hidayati, N. R., \& Mumtahana, H. A. (2019). Rancang Bangun Sistem Pendukung Keputusan Menentukan Nilai Harga Tanah Berbasis Website dengan Metode Analytical Hierarchy Process ( AHP ). 17-22.

Wendi, A., \& Ardiansyah. (2018). Perancangan Sistem Informasi Monitoring Installer Pada Pt Graha Sumber Prima Elektronik Jakarta. Jurnal Sistem Informasi, Teknologi Informasi Dan Komputer, 8(2), 105-118. https://jurnal.umj.ac.id/index.php/just-it/article/view/1841/2375 